\title{
Vaccine vectors: the bright side of cytomegalovirus
}

\author{
Andrea C. Méndez ${ }^{1} \cdot$ Cristina Rodríguez-Rojas $^{1} \cdot$ Margarita Del Val $^{1}[$
}

Received: 31 January 2019 / Accepted: 12 March 2019 / Published online: 21 March 2019

(c) Springer-Verlag GmbH Germany, part of Springer Nature 2019

\begin{abstract}
Cytomegaloviruses (CMVs) present singular features that are particularly advantageous for human vaccine development, a current medical need. Vaccines that induce neutralizing antibodies are among the most successful and efficacious available. However, chronic and persistent human infections, pathogens with high variability of exposed proteins, as well as tumors, highlight the need for developing novel vaccines inducing strong and long-lasting cellular immune responses mediated by effector or effector memory $\mathrm{CD} 8^{+}$cytotoxic $\mathrm{T}$ lymphocytes. CMV s induce the most potent $\mathrm{CD} 8^{+} \mathrm{T}$ lymphocyte response to a pathogen known in each of their hosts, maintain and even increase it for life for selected antigens, in what is known as the ever growing inflationary memory, and maintain an effector memory status due to recent and repeated antigen stimulation that endows these inflationary T lymphocytes with superior and faster protective potency. In addition to these CMV singularities, this family of viruses has two more common favorable features: they can superinfect an already infected host, which is needed in face of the high CMV prevalence, and they can harbor very large segments of foreign DNA at many different genomic sites. All these properties endow CMVs with a singular potential to be used as human vaccine vectors. Current developments with most of the recombinant CMV-based vaccine candidates that have been tested in animal models against clinically relevant viral and bacterial infections and for their use in tumor immunotherapy are reviewed herein. Since CMV vectors should be designed to avoid the risk of disease in immunocompromised individuals, special attention is also paid to attenuated vectors. Taken together, the results support the future use of CMV-based vaccine vectors to induce protective $\mathrm{CD}^{+} \mathrm{T}$ lymphocyte responses in humans, mainly against viral infections and as anti-tumor vaccines.
\end{abstract}

Keywords Cytomegalovirus $\cdot$ Vaccine vectors $\cdot \mathrm{CD}^{+} \mathrm{T}$ lymphocytes $\cdot$ Virus $\cdot$ Tumor $\cdot$ Immunotherapy

\section{Introduction}

Most human vaccines that are currently in use are based on the induction of humoral responses. However, this immune mechanism alone is not so efficient against intracellular pathogens that persist within the infected cell or against pathogens that rapidly gain mutations throughout their genome; for these pathogens, more conserved internal proteins would represent a more desirable target $[1,2]$. In both cases, a potent cellular immune response mainly based on

Edited by: Matthias J. Reddehase.

This article is part of the Special Issue on Immunological Imprinting during Chronic Infection.

Margarita Del Val

mdval@cbm.csic.es

1 Centro de Biología Molecular Severo Ochoa (CSIC-UAM), Nicolás Cabrera 1, 28049 Madrid, Spain
$\mathrm{CD} 8^{+} \mathrm{T}$ lymphocytes is also necessary for the elimination of the pathogen. Moreover, there are pathogens for which the natural immunity acquired after infection does not fully protect against reinfection and disease, and this makes it necessary to develop vaccines that are able to induce stronger responses than natural infection.

Cytomegaloviruses (CMVs) induce the strongest immune response known in clinical medicine [3] dominating the $\mathrm{T}$ lymphocyte memory compartment via a strong and long-lasting $\mathrm{CD} 8^{+} \mathrm{T}$ lymphocyte response that comprises an average $10 \%$ of the memory $\mathrm{CD} 8^{+} \mathrm{T}$ lymphocytes of the infected individual in mice and humans [3, 4]. This accounts for some $5 \%$ of total T lymphocytes in the average human blood, with wide variability among different persons [3]. As humans frequently harbor different strains, it is assumed that CMVs also have the ability to superinfect a previously infected host, which may represent an advantage to develop CMV-based vaccine vectors given the high worldwide prevalence of CMVs [5]. 
The large genome of CMVs is also a desirable quality to develop vaccine vectors allowing the insertion of multiple foreign genes, since more than $50 \mathrm{~kb}$ can be removed from human CMV (HCMV) without affecting virus replication [5]. A hallmark of $\mathrm{CD} 8^{+} \mathrm{T}$ lymphocyte responses against CMVs is memory inflation, which consists of an accumulation of certain $\mathrm{CMV}$-specific $\mathrm{CD}^{+} \mathrm{T}$ lymphocytes over time before stabilizing at a high frequency [4, 6-9]. These inflationary $\mathrm{CD} 8^{+} \mathrm{T}$ lymphocytes remain functional [6] and do not show signs of exhaustion even at late time points after infection $[10,11]$, and they display an effectorlike phenotype consistent with a repeated antigen stimulation $[8,12]$. Since effector memory cells respond rapidly upon pathogen re-encounter and are located in peripheral tissues, these cells would be the most interesting population for efficient control of proliferating pathogens [13]. In addition, CMV has also been suggested as a good vaccine vector to induce long-lasting antibody responses, as mouse CMV (MCMV)-specific IgG responses can inflate in latently infected mice persisting long after infection [14].

CMV has several advantages for its use as a human vaccine vector platform compared with others such as poxviral, adenoviral or lentiviral vectors. Unlike the other candidates, both CMV and lentiviral vectors persist lifelong within their host; however, CMV vectors represent a safer alternative due to the oncogenic potential of lentiviruses [15]. Poxviral vectors based on attenuated vaccinia virus strains might have some inconveniences compared to CMV vectors in certain situations: poxviral vectors induce conventional memory $\mathrm{CD} 8^{+} \mathrm{T}$ lymphocyte responses, which do not inflate and have predominantly a central memory phenotype $[5,16]$. Adenoviral vectors can induce T lymphocyte responses similar to those induced by CMV in magnitude and kinetics against heterologous antigens [17, 18], but can only accommodate small inserts [19]. CMV vaccine vectors can be used in previously seropositive hosts due to the superinfection capacity of CMV, and this also allows an efficient repeated administration of CMV vaccine vectors [5]. Together with the effector nature of CMV-induced memory $\mathrm{T}$ lymphocytes, this represents a major advantage of CMV as a vaccine vector compared with poxviral vectors (although their seroprevalence in the population is decreasing after the eradication of smallpox) and especially adenoviral vectors, as some serotypes are highly prevalent.

In this review, we have compiled most of the CMV-based vaccine candidates developed to this date, focusing on the design of safe attenuated vectors and on vaccine candidates engineered against diseases caused by viral and bacterial infections that have been tested in animal models. We also pay special attention to CMV-based vaccine candidates designed for cancer immunotherapy in mouse models.

\section{Attenuated CMV vaccine vectors}

The use of CMV vectors carries the risk of CMV disease in immunocompromised hosts, including the relatively high frequency and serious outcome of congenital infection by HCMV [20], unless the vaccine vector is controlled efficiently by the residual immunity while eliciting a strong protective immune response. Thus, it is necessary to devote efforts to develop safe CMV-based vaccine vectors. An approach to generate immunogenic and safe vaccines is the use of replication-deficient or spreaddeficient CMVs, which interestingly can still drive CD8 ${ }^{+}$ $\mathrm{T}$ lymphocyte memory inflation against MCMV epitopes in mice when administered systemically [21]. A spreaddeficient HCMV has also been shown to induce antibody, $\mathrm{CD}^{+}$and $\mathrm{CD} 8^{+} \mathrm{T}$ lymphocyte responses in non-human primates [22]. However, an ideal CMV-based vaccine candidate should be severely attenuated in vivo even in immune-compromised hosts, but should grow to high titers in cell culture for easy production [23], and the production of spread-deficient CMVs requires the expression in trans of the genes that are necessary for viral replication in the cell types used for production.

Another approach to design attenuated CMV-based vaccine candidates is the deletion of viral genes that interfere with the host immune response or even the insertion of ligands recognized by activating receptors on immune cells. The main efforts to develop attenuated CMV vaccine candidates following the latter strategy have been carried out by Jonjic's team, showing that recombinant CMVs expressing ligands of the activating NK cell receptor NKG2D can be used as efficient vaccines. Based on the relevance of the NKG2D signaling pathway for CMV control, as illustrated by the four MCMV proteins dedicated to downmodulate NKG2D ligands from the surface of infected cells [24], they first studied a recombinant MCMV expressing the NKG2D ligand RAE- $1 \gamma$ in place of its viral inhibitor m152/gp40 [25]. With this design, the goal was to prevent downregulation of endogenous RAE-1 proteins by $\mathrm{m} 152 / \mathrm{gp} 40$ and to additionally express high levels of an NKG2D ligand, which would increase NK cell activation and also potentiate $\mathrm{CD} 8^{+} \mathrm{T}$ lymphocyte effector function due to the costimulatory role of NKG2D on these cells [26]. In addition, since m152/gp40 also retains MHC class I molecules in the secretory pathway $[27,28]$, the deletion of this protein might also improve antigen presentation to $\mathrm{CD} 8^{+} \mathrm{T}$ lymphocytes; however, the elimination of all three MCMV immune evasion proteins that interfere with antigen presentation by MHC class I molecules might be counterproductive when eliciting strong $\mathrm{CD}^{+} \mathrm{T}$ lymphocyte responses [29].

Despite being attenuated in vivo even in newborn and immunocompromised mice, RAE- $1 \gamma$ expressing 
MCMV induced $\mathrm{CD} 8^{+} \mathrm{T}$ lymphocyte responses against viral epitopes which were protective against a challenge with WT MCMV, and also induced protective antibodies [25]. These results encouraged testing MCMV expressing RAE- $1 \gamma$ as a vaccine candidate to induce protective $\mathrm{CD} 8^{+}$ $\mathrm{T}$ lymphocyte responses. Following pioneering work with single $\mathrm{CD} 8^{+} \mathrm{T}$ lymphocyte epitope vaccines [30], this vector was first tested as a vaccine against Listeria monocytogenes infection, expressing a single $\mathrm{CD} 8^{+} \mathrm{T}$ lymphocyte epitope of L. monocytogenes or the $\mathrm{CD}^{+} \mathrm{T}$ lymphocyte model epitope SIINFEKL from ovalbumin (OVA) in place of the MCMV inflationary epitope of $\mathrm{m} 164$ presented by $\mathrm{H}-2 \mathrm{D}^{\mathrm{d}}$ [31]. L. monocytogenes expressing SIINFEKL was used in challenges when required to test the model in the C57BL/6 background. In both BALB/c and C57BL/6 mice, vaccination with the RAE- $1 \gamma$ expressing vaccine candidate conferred a remarkable protection against challenge, which was mediated by strong antigen-specific $\mathrm{CD} 8^{+} \mathrm{T}$ lymphocyte responses that remained functional even 11 months after immunization. The authors suggest that these results might be explained by a novel function of RAE- $1 \gamma$ which would be independent of NKG2D and increase the strength and persistence of $\mathrm{CD}^{+} \mathrm{T}$ lymphocyte responses, since both the in vivo attenuation of the virus and the strong protection against $L$. monocytogenes challenge are maintained in NKG2D-deficient mice [31]. MCMV expressing RAE- $1 \gamma$ and SIINFEKL model epitope has also been used as a vaccine candidate against a melanoma model expressing OVA [32] (more details in "CMV vaccine candidates in cancer immunotherapy").

Jonjic's team has also tested another recombinant MCMV expressing an NKG2D ligand. In this case, the high-affinity NKG2D ligand MULT-1 is expressed in place of its viral inhibitor $\mathrm{m} 145$. This vector is attenuated in vivo in a way comparable to or stronger than the MCMV expressing RAE- $1 \gamma$ and induces a similar magnitude of CD8 ${ }^{+} \mathrm{T}$ lymphocyte and antibody responses, which are protective against a challenge with WT MCMV [33]. Thus, MULT-1 expressing MCMV might also serve as a good vaccine against heterologous challenges.

\section{CMV-based vaccine candidates against diseases caused by viruses}

The first description of a recombinant CMV as a vaccine candidate against a pathogen involved two MCMVs expressing $\mathrm{CD}^{+} \mathrm{T}$ lymphocyte epitopes of the influenza A virus nucleoprotein (NP) or of the lymphocytic choriomeningitis virus glycoprotein (GP) [7]. In both MCMVs, the corresponding epitope was fused to the $\mathrm{C}$-terminus of the IE2 protein, and inflationary $\mathrm{CD} 8^{+} \mathrm{T}$ lymphocyte responses were induced against the exogenous epitopes. Both MCMVs protected mice against challenges with a vaccinia virus expressing the corresponding exogenous epitope, with maintenance of protection up to 200 days post-infection [7]. These results prompted the development of several CMVbased vaccine candidates targeting clinically relevant viral infections. The most relevant are reviewed in the text and summarized in Table 1.

\section{CMV vaccines for Sin Nombre virus (SNV)}

SNV is a hantavirus that causes a severe pulmonary syndrome in humans and whose natural reservoir is deer mouse (Peromyscus maniculatus). As a way of preventing the disease by vaccinating the natural host, a recombinant Peromyscus CMV (PCMV) expressing the GP G1 of SNV fused to the enhanced green fluorescent protein (EGFP) was developed and tested for immunogenicity in deer mice [34, 35]. This PCMV immunogen induced antibodies against G1 [34]; however, no studies of its protective capacity against an SNV challenge have been reported. The latest efforts to protect humans from SNV infection are focused on DNA vaccines [36].

\section{CMV vaccines for human immunodeficiency virus (HIV), using simian immunodeficiency virus (SIV) as a model}

The rapid onset of massive and systemic viral replication during primary HIV infection, HIV variability and its capacity to establish a latent infection with genome integration represent a huge challenge to develop a vaccine against HIV [37]. Adenoviral vectors have been tested in clinical trials; however, one of the most promising HIV vaccines based on an adenoviral vaccine candidate not only failed to induce protective responses but also increased the infection risk of some human subgroups [38, 39]. Poxviral vectors based on modified vaccinia Ankara (MVA) have also been tested in clinical trials yielding good immunogenicity [40, 41], but repeated immunizations seem to preferentially potentiate antibody responses instead of $\mathrm{T}$ lymphocytes, which would be highly desirable against HIV [42]. Thus, CMV could be a good candidate as a vaccine vector with the aim of generating effector memory $\mathrm{CD} 8^{+} \mathrm{T}$ lymphocytes that could act immediately at viral entry sites, impairing viral replication at its earliest stage.

Picker et al. [43] developed a set of vaccine candidates based on rhesus monkey CMV (RhCMV) expressing several proteins of the SIV on the RhCMV strain $68-1$ backbone: the first expressed the SIV Gag protein, the second a RevTat-Nef fusion protein and the third the Env protein. All three vaccines induced specific $\mathrm{CD}^{+}$and $\mathrm{CD}^{+}{ }^{+} \mathrm{T}$ lymphocyte responses with an effector memory phenotype, but even the Env-expressing candidate did not induce neutralizing 


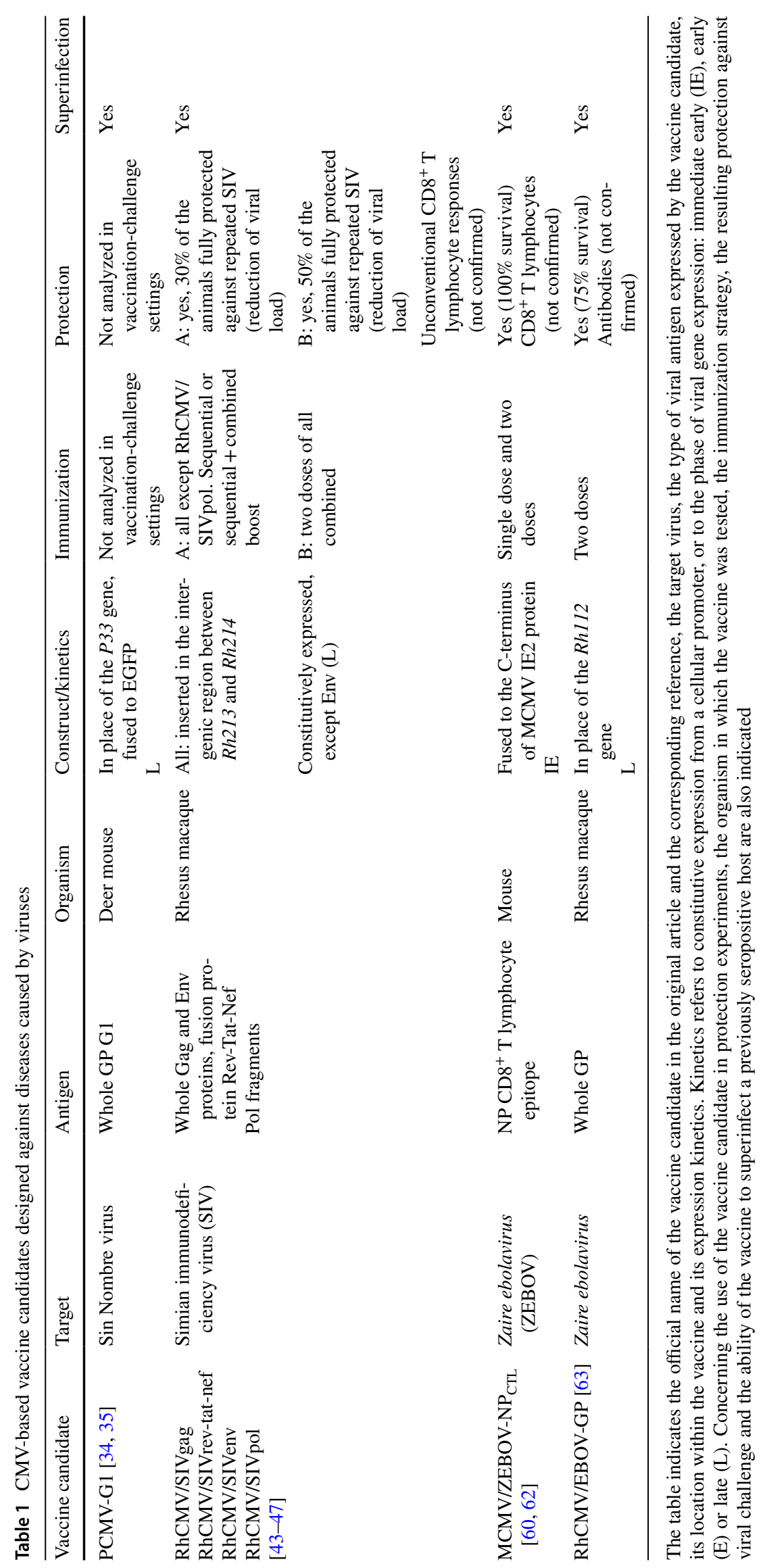


antibodies. When the three vaccines were administered sequentially to analyze their protective capacity against SIV challenge, a protective effect was observed in terms of increased resistance to repeated progressive SIV infection and even complete resistance in $30 \%$ of the vaccinated macaques [43]. A second study was performed with two additional vaccine candidates expressing SIV Pol fragments [44]. Simultaneous vaccination with the five RhCMV vaccines combined or not with an adenoviral vaccine induced long-term complete control of repeated SIV challenges in $50 \%$ of the animals, with a correlation between the magnitude of SIV-specific $\mathrm{CD} 8^{+} \mathrm{T}$ lymphocyte responses and protection [44]. In a third study [45], it was shown that SIV persisted in different sites for several weeks after challenge of vaccinated macaques, but was progressively lost over time in those protected by the RhCMV vaccines, and protected macaques could not be differentiated from vaccinated macaques not exposed to SIV challenge. Surprisingly, it was observed that the RhCMV vaccine candidates used in these studies elicited $\mathrm{CD} 8^{+} \mathrm{T}$ lymphocyte responses mostly against epitopes restricted by MHC class II molecules [46]. Several deletions due to sequential passaging in fibroblasts were identified in the $68-1$ backbone. Specifically, the repair of the RhCMV orthologs of HCMV UL128 and UL130 (Rh157.5 and Rh157.4), which are involved in RhCMV tropism for non-fibroblasts as part of the pentameric GP complex, resulted in conventional MHC class I restricted responses [46]. Moreover, at least the RhCMV vaccine candidate expressing Gag protein elicited $\mathrm{CD} 8^{+} \mathrm{T}$ lymphocytes that recognize peptides presented by the nonpolymorphic MHC-E molecule [47]. Although there is no direct evidence for the protective capacity of unconventional $\mathrm{CD}^{+} \mathrm{T}$ lymphocyte responses elicited by $68-1 \mathrm{RhCMV}$, no other SIV-specific CD8 ${ }^{+} \mathrm{T}$ lymphocytes were detected in protected RhCMV-vaccinated macaques [46]. The fact that these responses are different from those induced by the natural SIV infection prompted the study of T lymphocyte responses in humans who had been vaccinated with HCMV vaccine vectors with the same alterations as $68-1 \mathrm{RhCMV}$. Four fibroblast-adapted HCMV vaccines that are chimeras of Towne and Toledo strains and were developed in the context of generating a vaccine against HCMV have been tested in humans, all with cellular tropism limited to fibroblasts and lacking the pentameric complex as the $68-1 \mathrm{RhCMV}$, although the specific genetic defect is limited to UL128 in the Towne/Toledo chimeras [48]. In a phase I clinical trial, these four HCMVs were reported to induce only conventional $\mathrm{CD}^{+} \mathrm{T}$ lymphocyte responses, with no direct evidence of $\mathrm{CD} 8^{+} \mathrm{T}$ lymphocytes restricted by HLA class II molecules or HLA-E [49]. However, it has been suggested $[46,50]$ that one or more of the proteins encoded in the orthologs of $U L 128$ and $U L 131$ genes absent in the $68-1$ backbone could have an additional function that affects
$\mathrm{CD}^{+} \mathrm{T}$ lymphocyte priming. Other important inconveniences of these Towne/Toledo chimeras are their inability to superinfect seropositive individuals [51] and their induction of $\mathrm{CD} 8^{+} \mathrm{T}$ lymphocyte responses that do not have an effector phenotype [52].

\section{CMV vaccines for Ebola virus (EBOV)}

EBOV causes a severe form of viral hemorrhagic fever in humans, representing a serious health concern in Central Africa due to its high lethality. Although to this date there are no licensed vaccines against EBOV, a vaccine candidate based on vesicular stomatitis virus expressing the surface GP of Zaire ebolavirus (ZEBOV), has been shown to induce substantial protection against disease in a ring vaccination trial in humans [53] and has been used in EBOV outbreaks in some parts of Africa. The protection provided by this vaccine has been linked to its induction of antibody responses [54], although it was shown to induce both humoral and cellular immune responses in non-human primates [55], a quality that was thought to be crucial for the design of vaccines against EBOV [56]. Other approaches based on recombinant adenoviral and poxviral vaccine vectors are being currently developed [57-59]. However, considering that CMV induces strong immune responses and has the ability to superinfect and disseminate through target populations, Jarvis' team has proposed the possibility of developing a vaccine based on chimpanzee/gorilla-specific CMV vectors that could be used in forest regions where the use of individual vaccination strategies is not possible [60]. These vectors would prevent infection in great apes, which are endangered by EBOV infection but might also represent a significant source of transmission to humans [61].

The first CMV vaccine candidate designed against EBOV was an MCMV expressing an NP $\mathrm{CD}^{+} \mathrm{T}$ lymphocyte epitope of ZEBOV fused to the C-terminus of the MCMV IE2 protein [60]. This vaccine candidate was able to protect all vaccinated mice against a lethal ZEBOV challenge presumably by the induction of NP-specific $\mathrm{CD}^{+} \mathrm{T}$ lymphocytes with inflationary kinetics and an effector phenotype, both in a two-dose setting [60] and after a single vaccination dose [62]. More recently, an RhCMV vaccine candidate against EBOV has been tested in rhesus macaques, expressing the whole GP of EBOV [63]. This vaccine conferred protection against a lethal EBOV challenge, although less efficiently than the MCMV vaccine, and induced GP-specific IgG antibody responses while GP-specific $\mathrm{CD} 4^{+}$and $\mathrm{CD} 8^{+}$ T lymphocytes were not detected [63]. Considering that protection was stronger in mice vaccinated with the MCMV expressing a single $\mathrm{CD} 8^{+} \mathrm{T}$ lymphocyte epitope, this might indicate that applying this design to RhCMV vaccine candidates could be more convenient, pointing to a relevance of 
effector $\mathrm{CD} 8^{+} \mathrm{T}$ lymphocyte responses on vaccine-induced protection against EBOV.

\section{CMV-based vaccine candidates against diseases caused by bacteria}

CMV-based vaccine vectors have been proposed as a tool to generate vaccines against clinically relevant bacterial infections, solving some of the problems associated with currently available vaccines. The most relevant are reviewed in the text below and summarized in Table 2, together with the attenuated MCMV expressing RAE- $1 \gamma$ tested as a vaccine against $L$. monocytogenes (see "Attenuated CMV vaccine vectors" for details).

\section{CMV vaccines for tetanus}

The use of the widespread inactivated tetanus toxin vaccine has reduced considerably the incidence of tetanus disease in developed countries, and multi-dose vaccination is reducing neonatal tetanus, which is the most common form of the disease in developing countries. Maternal antibodies are necessary for prevention of neonatal tetanus, and the induction of long-lasting protective antibodies could be a solution to avoid the logistic and cost problems associated with the several doses needed with the inactivated vaccine. Thus, a CMV-based vaccine inducing antibody responses has been proposed as a good option due to the persistent immune responses induced by latent CMV. An MCMV expressing non-toxic tetanus toxin fragment $\mathrm{C}$ has been tested in mice, inducing a specific antibody response that was lower in magnitude and developed slower than the one induced by the conventional vaccine but did not decay over time, and had neutralizing capacity ex vivo [64].

\section{CMV vaccines for tuberculosis}

Tuberculosis (TB) remains an important cause of morbidity and mortality worldwide, aggravated by the spread of drug-resistant organisms and coinfection with HIV. Bacillus Calmette-Guérin (BCG), which is derived from Mycobacterium bovis, is currently the only licensed vaccine against TB, but it is not completely efficacious. There has been a strategy based on vaccine vectors to boost the protective capacity of BCG vaccine, using a recombinant MVA which yielded poor results in animal models [65] and also failed in clinical trials [66]. On the other hand, boosting strategies based on adenoviral vaccine candidates showed a modest enhancement of the protection conferred by BCG in animal models [67-70]. Expecting that these vectors may fail to elicit sustained $\mathrm{T}$ lymphocyte responses, CMV-based vaccines against Mycobacterium tuberculosis have been designed and tested in mouse [71] and rhesus macaque [72] models to develop a better vaccine. Although in both cases CMV-based vaccine candidates have induced protective responses, their protective capacity was more dependent on the induction of innate immune responses, and this may limit their long-term efficacy.

In the first case, an MCMV lacking the first 16 genes of the virus (including two genes that interfere with MHC class I expression) was used as a vaccine candidate expressing the M. tuberculosis mycolyl transferase $85 \mathrm{~A}$ in place of the deleted genes [71]. This vaccine candidate conferred protection in terms of reduction of mycobacterial load comparable to BCG and an adenoviral vaccine, in spite of the fact that anti-85A CD8 ${ }^{+}$and $\mathrm{CD} 4^{+} \mathrm{T}$ lymphocyte responses were not detectable ex vivo in mice vaccinated with the MCMV expressing 85A, and were only detectable after in vivo boosting. The reduction of mycobacterial load by vaccination with the MCMV85A candidate was shown to be dependent on NK cell responses, with a probable minor contribution of 85A-specific $\mathrm{T}$ lymphocyte responses [71].

In the second case, RhCMV vaccine candidates encoding M. tuberculosis antigen inserts conferred better protection than BCG in rhesus macaques against the disease induced by mycobacterial challenge [72]. A set of four RhCMV vaccine candidates encoding nine proteins of $M$. tuberculosis using the 68-1 RhCMV backbone (with the original goal of eliciting unconventional $\mathrm{CD} 8^{+} \mathrm{T}$ lymphocyte responses) was first used, together with the set of controls designed in a repaired $68-1.2$ backbone. Another strategy using a $68-1$ RhCMV encoding six of the antigens above in a single polyprotein was also applied. All RhCMV vaccines were shown to induce specific $\mathrm{CD} 4^{+}$and $\mathrm{CD} 8^{+} \mathrm{T}$ lymphocyte responses against the $M$. tuberculosis antigens. In the first vaccination study with the set of four 68-1 RhCMVs, protection from TB disease was better than with BCG. Unexpectedly, combined vaccination with RhCMVs and BCG resulted in worse protection from disease than vaccination with $\mathrm{RhC}$ MVs alone. Vaccination with the set of four repaired 68-1.2 RhCMVs, as well as with the 68-1 RhCMV encoding six antigens was as protective against TB disease as the first vaccination strategy. Protection was probably not mediated by the unconventional $\mathrm{CD} 8^{+} \mathrm{T}$ lymphocyte responses, as these were elicited only by the RhCMVs designed in the original $68-1$ backbone. Instead, the only immunological feature that could be used as a predictive marker of protection was a high expression of genes associated with neutrophil degranulation and neutrophil effector functions. Thus, the key protective mechanism behind these RhCMV vaccine candidates is probably based on innate immunity, although the authors suggest an involvement of $\mathrm{CD}^{+} \mathrm{T}$ lymphocytes and also point to the need of analyzing $\mathrm{T}$ lymphocyte responses directly in lung tissue or lung-draining lymph 


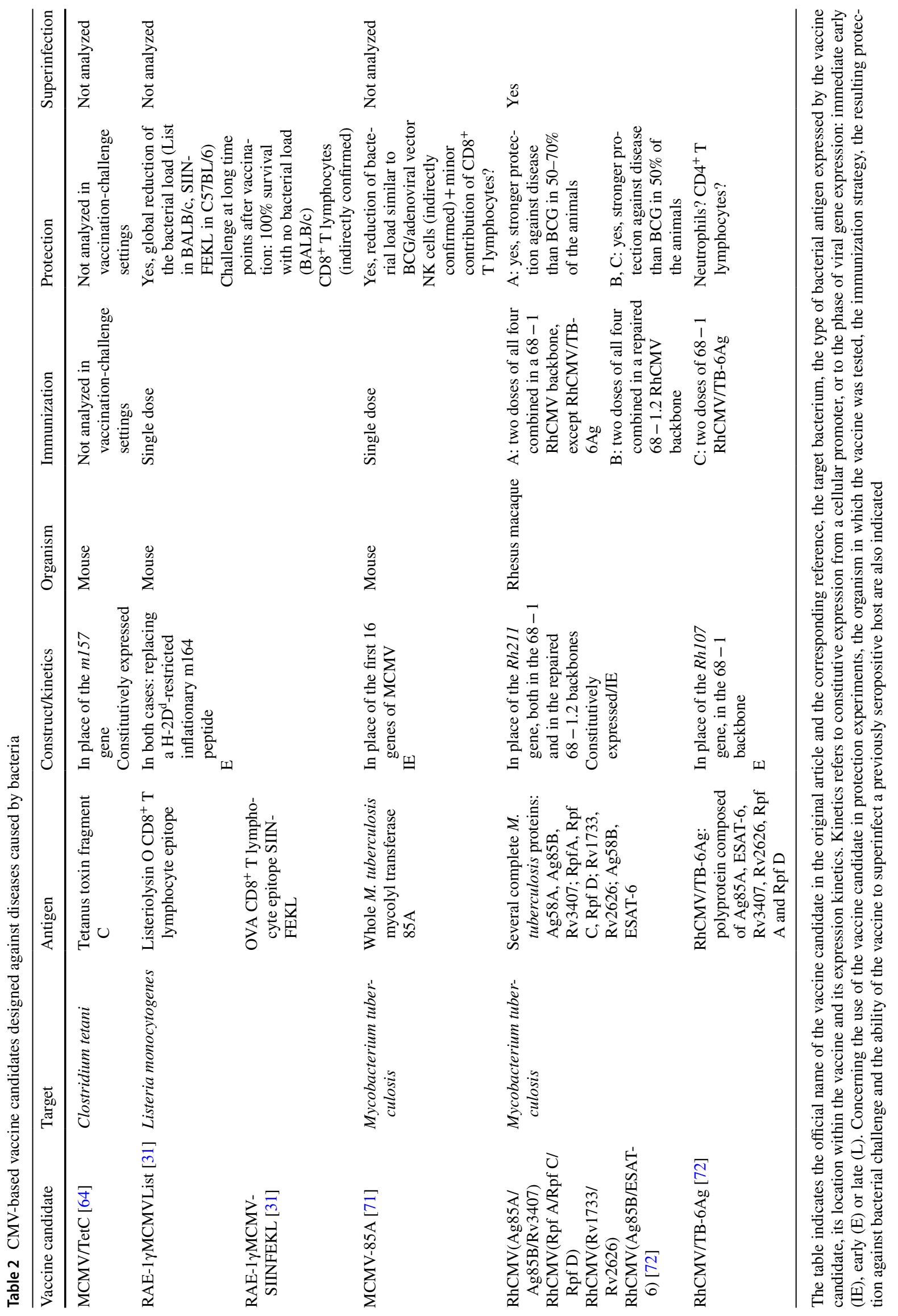


nodes, as those might be the populations actually relevant for protection [72].

\section{CMV vaccine candidates in cancer immunotherapy}

One of the main strategies of cancer immunotherapy is the generation and potentiation of $\mathrm{CD} 8^{+} \mathrm{T}$ lymphocyte responses against tumor-specific antigens. Tumor infiltration by $\mathrm{CD}^{+} \mathrm{T}$ lymphocytes is associated with regression of solid tumors and with a better prognosis [73], and adoptive transfer of autologous tumor-specific $\mathrm{CD}^{+} \mathrm{T}$ lymphocytes has a great potential in clinical applications especially when these cells are engineered to improve their anti-tumor properties such as in the example of chimeric antigen receptor (CAR) T lymphocytes [74-76]. Although some tumorspecific $\mathrm{CD} 8^{+} \mathrm{T}$ lymphocyte epitopes have been identified in host proteins [77], there are no vaccines available to elicit $\mathrm{CD}^{+} \mathrm{T}$ lymphocyte responses to eliminate solid tumors and prevent their reoccurrence. Since a good vaccine candidate should induce highly efficient effector $\mathrm{CD}^{+} \mathrm{T}$ lymphocytes that are capable of persisting and eliminating tumor cells early upon occurrence, CMV-based vaccines are a promising strategy in this field. Several MCMV-based vaccine candidates have been developed for this purpose and tested in mouse models, and are reviewed below and summarized in Table 3.

The first CMV-based vaccine candidates designed for cancer immunotherapy [78] were recombinant MCMVs expressing the whole human prostate-specific antigen (PSA), replacing the $m 157$ gene to avoid the strong NK cell-mediated control of MCMV in the C57BL/6 background [79, 80], or expressing a $\mathrm{CD} 8^{+} \mathrm{T}$ lymphocyte epitope of PSA fused to the C-terminus of IE2 also in the absence of $m 157$. These MCMV vaccine candidates were tested in mouse models expressing PSA as a self-antigen in the prostate in a tumor-permissive background, and while both were able to induce inflationary $\mathrm{CD}^{+} \mathrm{T}$ lymphocyte responses against PSA, the MCMV expressing the single epitope induced a stronger delay of tumor growth and was the only vaccine candidate providing prolonged survival after inoculation of PSA-expressing adenocarcinoma of the mouse prostate [78].

Recombinant MCMVs have also been successfully used in the B16 melanoma model. The first one was the recombinant MCMV developed by Hill et al. [81], which expressed the complete form of the mouse melanoma antigen tyrosinase-related protein 2 (TRP2). This vaccine candidate provided complete protection against tumor development in a prophylactic setting and delayed tumor development in a therapeutic setting, and these protective effects were mediated by anti-TRP2 antibodies. Interestingly, a spread-deficient variant of the same vaccine had similar protective effects [81].

The second study in this context used an MCMV expressing the whole melanoma differentiation antigen gp100 [82], where the epitope contained in gp100 was modified to increase its binding affinity to MHC class I molecules. This vaccine candidate induced modest anti-gp100 cross-reactive $\mathrm{CD}^{+} \mathrm{T}$ lymphocyte responses with inflationary kinetics that caused a reduction in the tumor burden in the lungs of B16-challenged mice in prophylactic and therapeutic settings, although mice eventually succumbed to disease [82]. Its protective anti-tumor effect was improved when used in combination with adoptive transfer of tumor-specific $\mathrm{CD} 8^{+}$ $\mathrm{T}$ lymphocytes, but not when combined with immune checkpoint inhibitors [83]. Another recombinant MCMV expressing gp100 has been tested, in this case expressing only the $\mathrm{CD} 8^{+} \mathrm{T}$ lymphocyte epitope fused to the C-terminus of the GFP [84]. The gp100 epitope was modified to increase its immunogenicity. This vaccine candidate was inefficient in a therapeutic setting when administered systemically, but induced a strong reduction of tumor growth and improved survival after intratumoral administration regardless of the presence of gp00 in the vaccine, and these effects were improved when administered in combination with immune checkpoint inhibitors [84]. The anti-tumoral activity of this vaccine candidate might be associated to its ability to infect tumor-associated macrophages and to an improvement of the function of pre-existing tumor-specific $\mathrm{CD} 8^{+} \mathrm{T}$ lymphocytes $[84,85]$.

MCMV-based vaccine candidates have been also tested in a model of human papillomavirus (HPV) induced cancer in mice, using transformed TC-1 squamous carcinoma cells expressing the proteins E6 and E7 of HPV. Protection against tumor challenge was more efficient when using an MCMV expressing a CD8 ${ }^{+} \mathrm{T}$ lymphocyte epitope of the E7 protein fused to the C-terminus of IE2 compared to several MCMVs expressing the whole sequence of E6 and E7 proteins $[86,87]$. When administered intraperitoneally or subcutaneously, the vaccine candidate expressing the E7 epitope provided full $\mathrm{CD} 8^{+} \mathrm{T}$ lymphocyte-mediated protection against tumor challenge in a prophylactic setting, while intranasal administration, which induces a weaker E7-specific $\mathrm{CD}^{+} \mathrm{T}$ lymphocyte response, protected only $50 \%$ of the animals. A spread-deficient MCMV expressing the E7 epitope has also been tested in this context, providing also full protection in the prophylactic setting. Remarkably, the efficacy of these two vaccine candidates was impaired in mice with high levels of pre-existing immunity to MCMV, but maintained in those with low levels of pre-existing immunity. When used in therapeutic settings, vaccination with any of the two candidates expressing the E7 epitope delayed tumor growth [87]. 


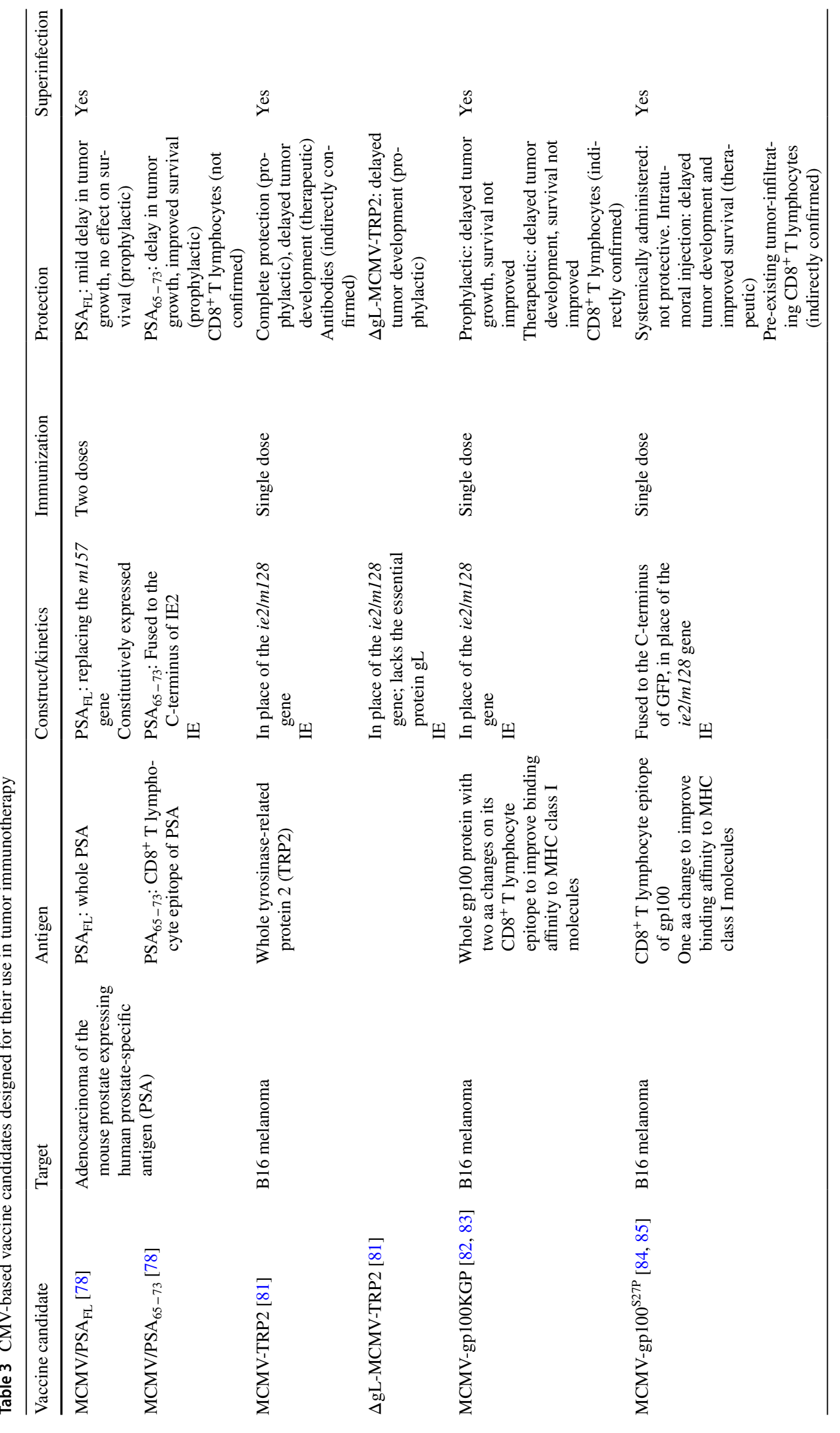




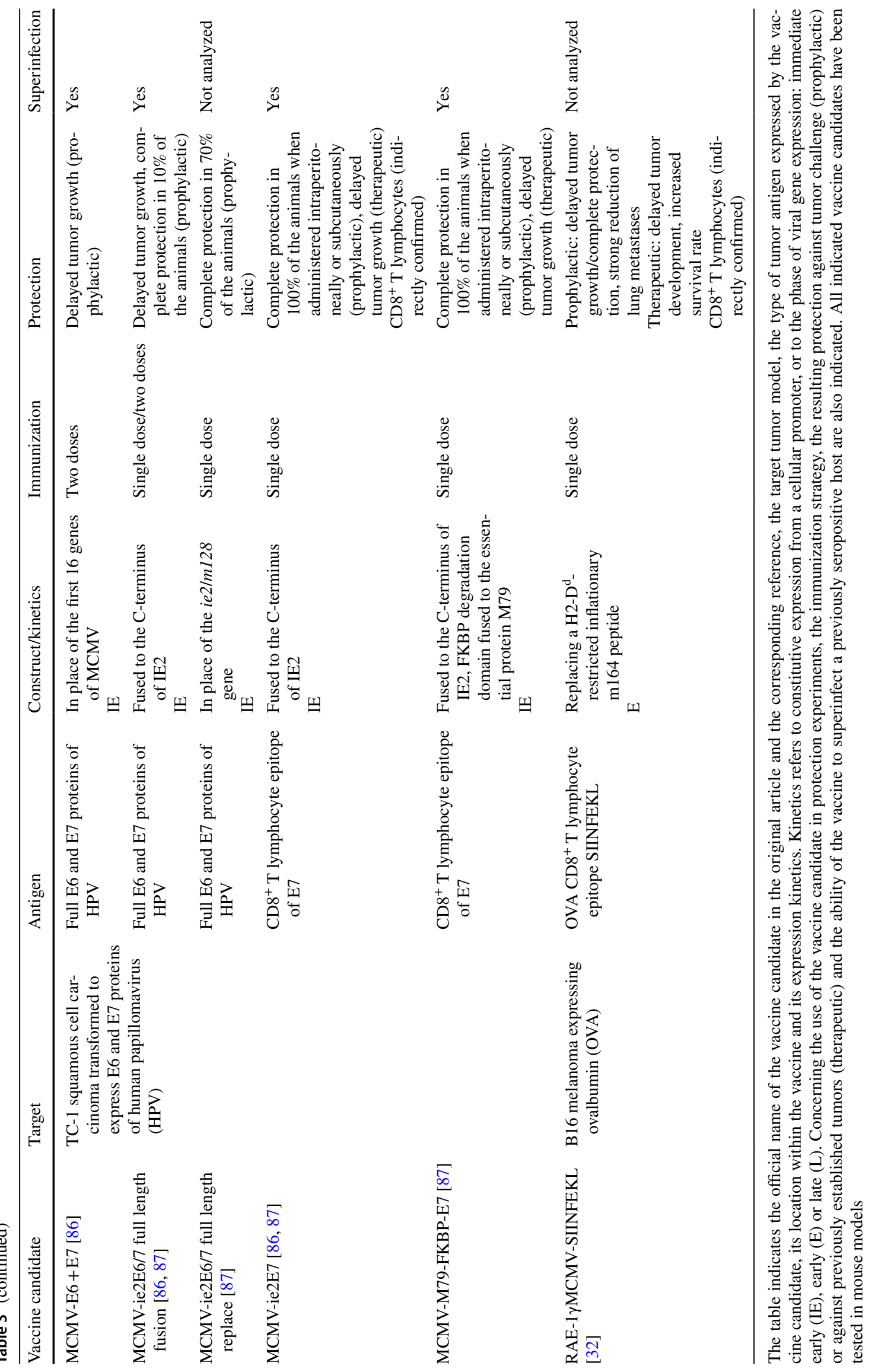


The attenuated RAE-1 $\gamma$ MCMV expressing SIINFEKL epitope (see also "Attenuated CMV vaccine vectors") has also been used as a vaccine against OVA-expressing B16 melanoma, delaying tumor formation or even preventing it completely in a prophylactic setting, presumably by the induction of effector SIINFEKL-specific $\mathrm{CD}^{+} \mathrm{T}$ lymphocytes. In addition, this vaccine candidate provided increased survival in a therapeutic setting, and in this case its effects were potentiated by the use of immune checkpoint inhibitors to reduce the immunosuppressive effects of the tumor [32].

\section{Considerations for an efficient design of CMV-based vaccine candidates}

To develop a CMV-based vaccine vector, it is necessary to know which type of foreign insert to use and where and how to insert it to induce the desired immune response, as the promoter used, the location of the epitope insertion and the epitope avidity are crucial factors for the efficacy of antigen processing and for memory inflation. The route of infection and the dose of the vaccine inoculum must be also considered, as these parameters can affect the strength of $\mathrm{CD} 8^{+}$ T lymphocyte responses [87, 88] and their kinetics [89]. Cicin-Sain's group has made crucial contributions on this topic. When analyzing the influence of the gene expression context on antigen-specific responses, they designed recombinant MCMVs expressing the immunodominant peptide of the $\mathrm{gB}$ of herpes simplex virus 1 (HSV-1) fused to the C-terminus of IE2 or of M45 and analyzed the strength, phenotype and kinetics of the $\mathrm{CD} 8^{+} \mathrm{T}$ lymphocyte responses, as well as their antiviral activity against HSV-1 challenge [90]. They observed that both recombinant MCMVs were equally protective against HSV-1, but induced different kinetics of $\mathrm{CD}^{+} \mathrm{T}$ lymphocyte responses: inflationary $\mathrm{CD} 8^{+} \mathrm{T}$ lymphocytes against the HSV-1 epitope when fused to IE2 and conventional when fused to M45. Interestingly, in both cases HSV-1 specific $\mathrm{CD}^{+} \mathrm{T}$ lymphocytes had an effector-like phenotype $[86,90]$.

The position of the epitope within the protein is also crucial for antigen processing and presentation and for the generation of $\mathrm{CD} 8^{+} \mathrm{T}$ lymphocyte responses [91]: when the non-inflationary epitope of M45 was inserted at the C-terminus of the protein instead of at its native site, the virus induced anti-M45 inflationary $\mathrm{CD} 8^{+} \mathrm{T}$ lymphocytes [86]. In addition, protection against tumor challenge and strength of $\mathrm{CD}^{+} \mathrm{T}$ lymphocyte responses were improved when using MCMV vaccines expressing a single tumor epitope fused to the C-terminus of an MCMV protein instead of the whole tumor protein $[78,86,87]$. Accordingly, most of the vaccine candidates reviewed in this article that have induced $\mathrm{CD} 8^{+}$ $\mathrm{T}$ lymphocyte protective responses in mouse models express single foreign epitopes instead of complete foreign proteins (Tables 1, 2, 3).

The intrinsic properties of the target epitope must also be considered to properly design a CMV-based vaccine candidate, as for example a $\mathrm{CD} 8^{+} \mathrm{T}$ lymphocyte epitope which binds to the TCR with low avidity can be protective as long as it is expressed in an inflationary gene context and induce strong responses based on effector-like inflationary $\mathrm{CD} 8^{+} \mathrm{T}$ lymphocytes [92]. These findings are particularly relevant considering that most tumor antigens have low immunogenicity [93]; however, the most immunogenic epitopes in quantitative terms may not always be the most efficient in antiviral protection [94].

The generation of inflationary $\mathrm{CD} 8^{+} \mathrm{T}$ lymphocyte responses might not always be the main goal when designing a CMV-based vaccine candidate: $\mathrm{CMV}$ can also induce tissue-resident memory $\mathrm{CD} 8^{+} \mathrm{T}$ lymphocytes, which can provide immediate local protection upon pathogen reexposure [95]. In fact, an MCMV vaccine candidate against respiratory syncytial virus (RSV) induces RSV-specific $\mathrm{CD} 8^{+} \mathrm{T}$ lymphocytes when administered systemically, but the immunization route is crucial when intending to induce tissue-resident memory $\mathrm{CD} 8^{+} \mathrm{T}$ lymphocytes in the lungs [96]. Recent evidence points to a long-term maintenance of effector anti-CMV $\mathrm{CD}^{+} \mathrm{T}$ lymphocytes in peripheral tissues in mice [96-98], although it is not clear whether this phenomenon occurs also in humans since most data available has been collected from peripheral blood samples [3].

\section{Concluding remarks}

The greatest challenge to design CMV vaccine candidates suitable for clinical use is to develop non-pathogenic vectors that could be safe for their use even in immunosuppressed individuals while retaining their immunogenicity and their capacity to infect previously seropositive hosts, avoiding also the risk of congenital infection. This has been achieved in mouse models, in which attenuated MCMVs have been shown to induce strong immune responses and, specifically, protective $\mathrm{CD} 8^{+} \mathrm{T}$ lymphocytes. However, none of the attenuated HCMV strains and recombinants tested up to this date are suitable as vector backbones. Thus, future efforts should probably focus on these systems for their future translation to clinics. Profiting from the extreme species specificity of CMVs, another possibility could be to directly use in humans vaccine candidates based on animal CMVs, as these CMVs would not replicate in human cells [99] and might represent a safe alternative.

As inflationary effector memory $\mathrm{T}$ lymphocytes are of considerable advantage, increased knowledge of the mechanisms of antigen processing and presentation by $\mathrm{MHC}$ class I molecules to $\mathrm{CD} 8^{+} \mathrm{T}$ lymphocytes that facilitate 
an inflationary response to any given foreign antigen is required. Moreover, more insights into the specific mechanisms of protection of CMV vaccine candidates would be necessary to improve their design, as well as a better understanding of the long-term effects of latent CMV infection on innate immunity and their interactions with the desired specific adaptive response. The heterogeneity of anti-HCMV $\mathrm{CD}^{+} \mathrm{T}$ lymphocyte responses in terms of both specificity and magnitude between different individuals must also be considered for an efficient design of CMV-based vaccine vectors [3].

Taken together, the results obtained in animal models up to this date support CMV vaccine vectors as promising candidates to develop new vaccines in the future and for their use in cancer immunotherapy, standing as a powerful tool to induce $\mathrm{CD}^{+} \mathrm{T}$ lymphocyte responses.

Acknowledgements The work in the laboratory was supported by Spanish Ministerio de Economía y Competitividad grants SAF201348754-C2-1-R and SAF2016-79607R and by Comunidad de Madrid grant B2017/BMD-3731 to M.D.V. and cofinanced by the European Regional Development Fund and the European Social Fund. A.C.M. was supported by Ayuda para contrato predoctoral para la formación de doctores 2014 BES-2014-068148 from Spanish Ministerio de Economía y Competitividad. C.R.R. was supported by Ayuda para la contratación de investigadores predoctorales PEJD-2017-PRE/BMD4692 from Spanish Consejería de Educación, Juventud y Deporte de la Comunidad de Madrid and cofinanced by the European Social Fund and the Youth Employment Initiative, and by Contrato predoctoral para la Formación de Profesorado Universitario FPU17/01914 from the Spanish Ministerio de Ciencia, Innovación y Universidades. Institutional grants from the Fundación Ramón Areces and Banco de Santander to the CBMSO are also acknowledged.

\section{Compliance with ethical standards}

Conflict of interest The authors declare that they have no conflict of interest.

\section{References}

1. Butler NS, Nolz JC, Harty JT (2011) Immunologic considerations for generating memory $\mathrm{CD} 8 \mathrm{~T}$ cells through vaccination. Cell Microbiol 13:925-933

2. Zinkernagel RM (2003) On natural and artificial vaccinations. Annu Rev Immunol 21:515-546

3. Sylwester AW, Mitchell BL, Edgar JB, Taormina C, Pelte C, Ruchti F, Sleath PR, Grabstein KH, Hosken NA, Kern F, Nelson JA, Picker LJ (2005) Broadly targeted human cytomegalovirusspecific CD4 + and CD8 + T cells dominate the memory compartments of exposed subjects. J Exp Med 202:673-685

4. Karrer U, Sierro S, Wagner M, Oxenius A, Hengel H, Koszinowski UH, Phillips RE, Klenerman P (2003) Memory inflation: continuous accumulation of antiviral CD $8+\mathrm{T}$ cells over time. J Immunol 170:2022-2029 [Correction appeared in J. Immunol. 171, 3895 (2003)]

5. Jarvis MA, Hansen SG, Nelson JA, Picker LJ, Fruh K (2013) Vaccine vectors using the unique biology and immunology of cytomegalovirus. In: Reddehase MJ (ed) Cytomegaloviruses: from molecular pathogenesis to intervention, Chap. 21, vol II. Caister Academic Press, Norfolk, pp 450-463

6. Holtappels R, Pahl-Seibert MF, Thomas D, Reddehase MJ (2000) Enrichment of immediate-early 1 (m123/pp89) peptide-specific CD8 T cells in a pulmonary CD62L(lo) memory-effector cell pool during latent murine cytomegalovirus infection of the lungs. $J$ Virol 74:11495-11503

7. Karrer U, Wagner M, Sierro S, Oxenius A, Hengel H, Dumrese T, Freigang S, Koszinowski UH, Phillips RE, Klenerman P (2004) Expansion of protective CD8 + T-cell responses driven by recombinant cytomegaloviruses. J Virol 78:2255-2264

8. Sierro S, Rothkopf R, Klenerman P (2005) Evolution of diverse antiviral CD8 + T cell populations after murine cytomegalovirus infection. Eur J Immunol 35:1113-1123

9. Munks MW, Cho KS, Pinto AK, Sierro S, Klenerman P, Hill AB (2006) Four distinct patterns of memory CD8 T cell responses to chronic murine cytomegalovirus infection. J Immunol 177:450-458

10. Podlech J, Holtappels R, Pahl-Seibert MF, Steffens HP, Reddehase MJ (2000) Murine model of interstitial cytomegalovirus pneumonia in syngeneic bone marrow transplantation: persistence of protective pulmonary CD8-T-cell infiltrates after clearance of acute infection. J Virol 74:7496-7507

11. Snyder CM, Cho KS, Bonnett EL, van Dommelen S, Shellam GR, Hill AB (2008) Memory inflation during chronic viral infection is maintained by continuous production of short-lived, functional T cells. Immunity 29:650-659

12. Masopust D, Ha SJ, Vezys V, Ahmed R (2006) Stimulation history dictates memory CD8 T cell phenotype: implications for primeboost vaccination. J Immunol 177:831-839

13. Sallusto F, Geginat J, Lanzavecchia A (2004) Central memory and effector memory $\mathrm{T}$ cell subsets: function, generation, and maintenance. Annu Rev Immunol 22:745-763

14. Welten SPM, Redeker A, Toes REM, Arens R (2016) Viral persistence induces antibody inflation without altering antibody avidity. J Virol 90:4402-4411

15. Lemiale F, Korokhov N (2009) Lentiviral vectors for HIV disease prevention and treatment. Vaccine 27:3443-3449

16. Picker LJ, Hansen SG, Lifson JD (2012) New paradigms for HIV/ AIDS vaccine development. Annu Rev Med 63:95-111

17. Bolinger B, Sims S, O'Hara G, de Lara C, Tchilian E, Firner S, Engeler D, Ludewig B, Klenerman P (2013) A new model for $\mathrm{CD}^{+} \mathrm{T}$ cell memory inflation based upon a recombinant adenoviral vector. J Immunol 190:4162-4174

18. Colston JM, Bolinger B, Cottingham MG, Gilbert S, Klenerman $\mathrm{P}$ (2016) Modification of antigen impacts on memory quality after adenovirus vaccination. J Immunol 196:3354-3363

19. Bett AJ, Haddara W, Prevec L, Graham FL (1994) An efficient and flexible system for construction of adenovirus vectors with insertions or deletions in early regions 1 and 3. Proc Natl Acad Sci U S A 91:8802-8806

20. Kenneson A, Cannon MJ (2007) Review and meta-analysis of the epidemiology of congenital cytomegalovirus (CMV) infection. Rev Med Virol 17:253-276

21. Snyder CM, Cho KS, Bonnett EL, Allan JE, Hill AB (2011) Sustained CD8 + T cell memory inflation after infection with a single-cycle cytomegalovirus. PLoS Pathog 7:e1002295

22. Wang D, Freed DC, He X, Li F, Tang A, Cox KS, Dubey SA, Cole S, Medi MB, Liu Y, Xu J, Zhang ZQ, Finnefrock AC, Song L, Espeseth AS, Shiver JW, Casimiro DR, Fu TM (2016) A replication-defective human cytomegalovirus vaccine for prevention of congenital infection. Sci Transl Med 8:362ra145

23. Cicin-Sain L, Bubic I, Schnee M, Ruzsics Z, Mohr C, Jonjic S, Koszinowski UH (2007) Targeted deletion of regions rich in immune-evasive genes from the cytomegalovirus genome as a novel vaccine strategy. J Virol 81:13825-13834 
24. Lisnic VJ, Krmpotic A, Jonjic S (2010) Modulation of natural killer cell activity by viruses. Curr Opin Microbiol 13:530-539

25. Slavuljica I, Busche A, Babic M, Mitrovic M, Gasparovic I, Cekinovic D, Markova Car E, Pernjak Pugel E, Cikovic A, Lisnic VJ, Britt WJ, Koszinowski U, Messerle M, Krmpotic A, Jonjic S (2010) Recombinant mouse cytomegalovirus expressing a ligand for the NKG2D receptor is attenuated and has improved vaccine properties. J Clin Invest 120:4532-4545

26. Markiewicz MA, Carayannopoulos LN, Naidenko OV, Matsui K, Burack WR, Wise EL, Fremont DH, Allen PM, Yokoyama WM, Colonna M, Shaw AS (2005) Costimulation through NKG2D enhances murine CD8 + CTL function: similarities and differences between NKG2D and CD28 costimulation. J Immunol 175:2825-2833

27. Del Val M, Hengel H, Hacker H, Hartlaub U, Ruppert T, Lucin P, Koszinowski UH (1992) Cytomegalovirus prevents antigen presentation by blocking the transport of peptide-loaded major histocompatibility complex class I molecules into the medial-Golgi compartment. J Exp Med 176:729-738

28. Ziegler H, Thäle R, Lucin P, Muranyi W, Flohr T, Hengel H, Farrell H, Rawlinson W, Koszinowski UH (1997) A mouse cytomegalovirus glycoprotein retains MHC class I complexes in the ERGIC/cis-Golgi compartments. Immunity 6:57-66

29. Bohm V, Simon CO, Podlech J, Seckert CK, Gendig D, Deegen P, Gillert-Marien D, Lemmermann NA, Holtappels R, Reddehase MJ (2008) The immune evasion paradox: immunoevasins of murine cytomegalovirus enhance priming of CD8 $\mathrm{T}$ cells by preventing negative feedback regulation. J Virol 82:11637-11650

30. Del Val M, Schlicht HJ, Volkmer H, Messerle M, Reddehase MJ, Koszinowski UH (1991) Protection against lethal cytomegalovirus infection by a recombinant vaccine containing a single nonameric T-cell epitope. J Virol 65:3641-3646

31. Trsan T, Busche A, Abram M, Wensveen FM, Lemmermann NA, Arapovic M, Babic M, Tomic A, Golemac M, Brinkmann MM, Jager W, Oxenius A, Polic B, Krmpotic A, Messerle M, Jonjic S (2013) Superior induction and maintenance of protective CD8 T cells in mice infected with mouse cytomegalovirus vector expressing RAE-1gamma. Proc Natl Acad Sci USA 110:16550-16555

32. Trsan T, Vukovic K, Filipovic P, Brizic AL, Lemmermann NAW, Schober K, Busch DH, Britt WJ, Messerle M, Krmpotic A, Jonjic S (2017) Cytomegalovirus vector expressing RAE-1gamma induces enhanced anti-tumor capacity of murine $\mathrm{CD} 8^{+} \mathrm{T}$ cells. Eur J Immunol 47:1354-1367

33. Hirsl L, Brizic I, Jenus T, Juranic Lisnic V, Reichel JJ, Jurkovic S, Krmpotic A, Jonjic S (2018) Murine CMV expressing the high affinity NKG2D ligand MULT-1: a model for the development of cytomegalovirus-based vaccines. Front Immunol 9:991

34. Rizvanov AA, van Geelen AG, Morzunov S, Otteson EW, Bohlman C, Pari GS, St Jeor SC (2003) Generation of a recombinant cytomegalovirus for expression of a hantavirus glycoprotein. J Virol 77:12203-12210

35. Rizvanov AA, Khaiboullina SF, van Geelen AG, St Jeor SC (2006) Replication and immunoactivity of the recombinant Peromyscus maniculatus cytomegalovirus expressing hantavirus G1 glycoprotein in vivo and in vitro. Vaccine 24:327-334

36. Hooper JW, Josleyn M, Ballantyne J, Brocato R (2013) A novel Sin Nombre virus DNA vaccine and its inclusion in a candidate pan-hantavirus vaccine against hantavirus pulmonary syndrome (HPS) and hemorrhagic fever with renal syndrome (HFRS). Vaccine 31:4314-4321

37. Walker BD, Burton DR (2008) Toward an AIDS vaccine. Science 320:760-764

38. Buchbinder SP, Mehrotra DV, Duerr A, Fitzgerald DW, Mogg R, Li D, Gilbert PB, Lama JR, Marmor M, Del Rio C, McElrath MJ, Casimiro DR, Gottesdiener KM, Chodakewitz JA, Corey L, Robertson MN (2008) Efficacy assessment of a cell-mediated immunity HIV-1 vaccine (the Step Study): a double-blind, randomised, placebo-controlled, test-of-concept trial. Lancet 372:1881-1893

39. Duerr A, Huang Y, Buchbinder S, Coombs RW, Sanchez J, del Rio C, Casapia M, Santiago S, Gilbert P, Corey L, Robertson MN (2012) Extended follow-up confirms early vaccine-enhanced risk of HIV acquisition and demonstrates waning effect over time among participants in a randomized trial of recombinant adenovirus HIV vaccine (step study). J Infect Dis 206:258-266

40. Garcia F, Bernaldo de Quiros JC, Gomez CE, Perdiguero B, Najera JL, Jimenez V, Garcia-Arriaza J, Guardo AC, Perez I, Diaz-Brito V, Conde MS, Gonzalez N, Alvarez A, Alcami J, Jimenez JL, Pich J, Arnaiz JA, Maleno MJ, Leon A, Munoz-Fernandez MA, Liljestrom P, Weber J, Pantaleo G, Gatell JM, Plana M, Esteban M (2011) Safety and immunogenicity of a modified pox vector-based HIV/AIDS vaccine candidate expressing Env, Gag, Pol and Nef proteins of HIV-1 subtype B (MVA-B) in healthy HIV-1-uninfected volunteers: a phase I clinical trial (RISVAC02). Vaccine 29:8309-8316

41. Gomez CE, Najera JL, Perdiguero B, Garcia-Arriaza J, Sorzano CO, Jimenez V, Gonzalez-Sanz R, Jimenez JL, Munoz-Fernandez MA, Lopez Bernaldo de Quiros JC, Guardo AC, Garcia F, Gatell JM, Plana M, Esteban M (2011) The HIV/AIDS vaccine candidate MVA-B administered as a single immunogen in humans triggers robust, polyfunctional, and selective effector memory $\mathrm{T}$ cell responses to HIV-1 antigens. J Virol 85:11468-11478

42. Guardo AC, Gomez CE, Diaz-Brito V, Pich J, Arnaiz JA, Perdiguero B, Garcia-Arriaza J, Gonzalez N, Sorzano COS, Jimenez L, Jimenez JL, Munoz-Fernandez MA, Gatell JM, Alcami J, Esteban M, de Quiros JC, Garcia F, Plana M (2017) Lopez Bernaldo. Safety and vaccine-induced HIV-1 immune responses in healthy volunteers following a late MVA-B boost 4 years after the last immunization. PLoS One 12:e186602

43. Hansen SG, Vieville C, Whizin N, Coyne-Johnson L, Siess DC, Drummond DD, Legasse AW, Axthelm MK, Oswald K, Trubey CM, Piatak M Jr, Lifson JD, Nelson JA, Jarvis MA, Picker LJ (2009) Effector memory T cell responses are associated with protection of rhesus monkeys from mucosal simian immunodeficiency virus challenge. Nat Med 15:293-299

44. Hansen SG, Ford JC, Lewis MS, Ventura AB, Hughes CM, Coyne-Johnson L, Whizin N, Oswald K, Shoemaker R, Swanson T, Legasse AW, Chiuchiolo MJ, Parks CL, Axthelm MK, Nelson JA, Jarvis MA, Piatak M Jr, Lifson JD, Picker LJ (2011) Profound early control of highly pathogenic SIV by an effector memory T-cell vaccine. Nature 473:523-527

45. Hansen SG, Piatak M Jr, Ventura AB, Hughes CM, Gilbride RM, Ford JC, Oswald K, Shoemaker R, Li Y, Lewis MS, Gilliam AN, Xu G, Whizin N, Burwitz BJ, Planer SL, Turner JM, Legasse AW, Axthelm MK, Nelson JA, Fruh K, Sacha JB, Estes JD, Keele BF, Edlefsen PT, Lifson JD, Picker LJ (2013) Immune clearance of highly pathogenic SIV infection. Nature 502:100-104

46. Hansen SG, Sacha JB, Hughes CM, Ford JC, Burwitz BJ, Scholz I, Gilbride RM, Lewis MS, Gilliam AN, Ventura AB, Malouli D, Xu G, Richards R, Whizin N, Reed JS, Hammond KB, Fischer M, Turner JM, Legasse AW, Axthelm MK, Edlefsen PT, Nelson JA, Lifson JD, Fruh K, Picker LJ (2013) Cytomegalovirus vectors violate $\mathrm{CD} 8^{+} \mathrm{T}$ cell epitope recognition paradigms. Science 340:1237874

47. Hansen SG, Wu HL, Burwitz BJ, Hughes CM, Hammond KB, Ventura AB, Reed JS, Gilbride RM, Ainslie E, Morrow DW, Ford JC, Selseth AN, Pathak R, Malouli D, Legasse AW, Axthelm MK, Nelson JA, Gillespie GM, Walters LC, Brackenridge S, Sharpe HR, Lopez CA, Fruh K, Korber BT, McMichael AJ, Gnanakaran S, Sacha JB, Picker LJ (2016) Broadly targeted CD8(+) T cell responses restricted by major histocompatibility complex E. Science 351:714-720 
48. Suarez NM, Lau B, Kemble GM, Lee R, Mocarski ES, Wilkinson GWG, Adler SP, McVoy MA, Davison AJ (2017) Genomic analysis of chimeric human cytomegalovirus vaccine candidates derived from strains Towne and Toledo. Virus Genes 53:650-655

49. Murray SE, Nesterenko PA, Vanarsdall AL, Munks MW, Smart SM, Veziroglu EM, Sagario LC, Lee R, Claas FHJ, Doxiadis IIN, McVoy MA, Adler SP, Hill AB (2017) Fibroblast-adapted human CMV vaccines elicit predominantly conventional CD8 T cell responses in humans. J Exp Med 214:1889-1899

50. Fruh K, Picker L (2017) CD8 + T cell programming by cytomegalovirus vectors: applications in prophylactic and therapeutic vaccination. Curr Opin Immunol 47:52-56

51. Heineman TC, Schleiss M, Bernstein DI, Spaete RR, Yan L, Duke G, Prichard M, Wang Z, Yan Q, Sharp MA, Klein N, Arvin AM, Kemble G (2006) A phase 1 study of 4 live, recombinant human cytomegalovirus Towne/Toledo chimeric vaccines. J Infect Dis 193:1350-1360

52. Adler SP, Manganello AM, Lee R, McVoy MA, Nixon DE, Plotkin S, Mocarski E, Cox JH, Fast PE, Nesterenko PA, Murray SE, Hill AB, Kemble G (2016) A phase 1 study of 4 live, recombinant human cytomegalovirus Towne/Toledo chimera vaccines in cytomegalovirus-seronegative men. J Infect Dis 214:1341-1348

53. Henao-Restrepo AM, Camacho A, Longini IM, Watson $\mathrm{CH}$, Edmunds WJ, Egger M, Carroll MW, Dean NE, Diatta I, Doumbia M, Draguez B, Duraffour S, Enwere G, Grais R, Gunther S, Gsell PS, Hossmann S, Watle SV, Konde MK, Keita S, Kone S, Kuisma E, Levine MM, Mandal S, Mauget T, Norheim G, Riveros X, Soumah A, Trelle S, Vicari AS, Rottingen JA, Kieny MP (2017) Efficacy and effectiveness of an rVSV-vectored vaccine in preventing Ebola virus disease: final results from the Guinea ring vaccination, open-label, cluster-randomised trial (Ebola Ca Suffit!). Lancet 389:505-518

54. Regules JA, Beigel JH, Paolino KM, Voell J, Castellano AR, Hu Z, Munoz P, Moon JE, Ruck RC, Bennett JW, Twomey PS, Gutierrez RL, Remich SA, Hack HR, Wisniewski ML, Josleyn MD, Kwilas SA, Van Deusen N, Mbaya OT, Zhou Y, Stanley DA, Jing W, Smith KS, Shi M, Ledgerwood JE, Graham BS, Sullivan NJ, Jagodzinski LL, Peel SA, Alimonti JB, Hooper JW, Silvera PM, Martin BK, Monath TP, Ramsey WJ, Link CJ, Lane HC, Michael NL, Davey RT Jr, Thomas SJ (2017) A recombinant vesicular stomatitis virus ebola vaccine. N Engl J Med 376:330-341

55. Jones SM, Feldmann H, Stroher U, Geisbert JB, Fernando L, Grolla A, Klenk HD, Sullivan NJ, Volchkov VE, Fritz EA, Daddario KM, Hensley LE, Jahrling PB, Geisbert TW (2005) Live attenuated recombinant vaccine protects nonhuman primates against Ebola and Marburg viruses. Nat Med 11:786-790

56. Marzi A, Feldmann H (2014) Ebola virus vaccines: an overview of current approaches. Expert Rev Vaccines 13:521-531

57. Zhu FC, Wurie AH, Hou LH, Liang Q, Li YH, Russell JB, Wu SP, Li JX, Hu YM, Guo Q, Xu WB, Wurie AR, Wang WJ, Zhang Z, Yin WJ, Ghazzawi M, Zhang X, Duan L, Wang JZ, Chen W (2017) Safety and immunogenicity of a recombinant adenovirus type-5 vector-based Ebola vaccine in healthy adults in Sierra Leone: a single-centre, randomised, double-blind, placebo-controlled, phase 2 trial. Lancet 389:621-628

58. Venkatraman N, Ndiaye BP, Bowyer G, Wade D, Sridhar S, Wright D, Powlson J, Ndiaye I, Dieye S, Thompson C, Bakhoum M, Morter R, Capone S, Sorbo MD, Jamieson S, Rampling T, Datoo M, Roberts R, Poulton I, Griffiths O, Ballou WR, Roman F, Lewis DJM, Lawrie A, Imoukhuede E, Gilbert SC, Dieye TN, Ewer KJ, Mboup S, Hill AVS (2018) Safety and immunogenicity of a heterologous prime-boost Ebola virus vaccine regimenChAd3-EBO-Z followed by MVA-EBO-Z in healthy adults in the UK and Senegal. J Infect Dis. https://doi.org/10.1093/infdis/jiy63 9
59. Lazaro-Frias A, Gomez-Medina S, Sanchez-Sampedro L, Ljungberg K, Ustav M, Liljestrom P, Munoz-Fontela C, Esteban M, Garcia-Arriaza J (2018) Distinct immunogenicity and efficacy of poxvirus-based vaccine candidates against Ebola Virus expressing GP and VP40 proteins. J Virol 92:e00363-e00318

60. Tsuda Y, Caposio P, Parkins CJ, Botto S, Messaoudi I, Cicin-Sain L, Feldmann H, Jarvis MA (2011) A replicating cytomegalovirusbased vaccine encoding a single Ebola virus nucleoprotein CTL epitope confers protection against Ebola virus. PLoS Negl Trop Dis 5:e1275

61. Leroy EM, Rouquet P, Formenty P, Souquiere S, Kilbourne A, Froment JM, Bermejo M, Smit S, Karesh W, Swanepoel R, Zaki SR, Rollin PE (2004) Multiple Ebola virus transmission events and rapid decline of central African wildlife. Science 303:387-390

62. Tsuda Y, Parkins CJ, Caposio P, Feldmann F, Botto S, Ball S, Messaoudi I, Cicin-Sain L, Feldmann H, Jarvis MA (2015) A cytomegalovirus-based vaccine provides long-lasting protection against lethal Ebola virus challenge after a single dose. Vaccine 33:2261-2266

63. Marzi A, Murphy AA, Feldmann F, Parkins CJ, Haddock E, Hanley PW, Emery MJ, Engelmann F, Messaoudi I, Feldmann H, Jarvis MA (2016) Cytomegalovirus-based vaccine expressing Ebola virus glycoprotein protects nonhuman primates from Ebola virus infection. Sci Rep 6:21674

64. Tierney R, Nakai T, Parkins CJ, Caposio P, Fairweather NF, Sesardic D, Jarvis MA (2012) A single-dose cytomegalovirusbased vaccine encoding tetanus toxin fragment $C$ induces sustained levels of protective tetanus toxin antibodies in mice. Vaccine 30:3047-3052

65. Kashangura R, Sena ES, Young T, Garner P (2015) Effects of MVA85A vaccine on tuberculosis challenge in animals: systematic review. Int J Epidemiol 44:1970-1981

66. Tameris MD, Hatherill M, Landry BS, Scriba TJ, Snowden MA, Lockhart S, Shea JE, McClain JB, Hussey GD, Hanekom WA, Mahomed H, McShane H (2013) Safety and efficacy of MVA85A, a new tuberculosis vaccine, in infants previously vaccinated with BCG: a randomised, placebo-controlled phase $2 \mathrm{~b}$ trial. Lancet 381:1021-1028

67. Forbes EK, Sander C, Ronan EO, McShane H, Hill AV, Beverley PC, Tchilian EZ (2008) Multifunctional, high-level cytokineproducing Th1 cells in the lung, but not spleen, correlate with protection against Mycobacterium tuberculosis aerosol challenge in mice. J Immunol 181:4955-4964

68. Xing Z, McFarland CT, Sallenave JM, Izzo A, Wang J, McMurray DN (2009) Intranasal mucosal boosting with an adenovirus-vectored vaccine markedly enhances the protection of BCG-primed guinea pigs against pulmonary tuberculosis. PLoS One 4:e5856

69. Dean G, Whelan A, Clifford D, Salguero FJ, Xing Z, Gilbert S, McShane H, Hewinson RG, Vordermeier M, Villarreal-Ramos B (2014) Comparison of the immunogenicity and protection against bovine tuberculosis following immunization by BCG-priming and boosting with adenovirus or protein based vaccines. Vaccine 32:1304-1310

70. Jeyanathan M, Shao Z, Yu X, Harkness R, Jiang R, Li J, Xing Z, Zhu T (2015) AdHu5Ag85A respiratory mucosal boost immunization enhances protection against pulmonary tuberculosis in BCG-primed non-human primates. PLoS One 10:e0135009

71. Beverley PC, Ruzsics Z, Hey A, Hutchings C, Boos S, Bolinger B, Marchi E, O’Hara G, Klenerman P, Koszinowski UH, Tchilian EZ (2014) A novel murine cytomegalovirus vaccine vector protects against Mycobacterium tuberculosis. J Immunol 193:2306-2316

72. Hansen SG, Zak DE, Xu G, Ford JC, Marshall EE, Malouli D, Gilbride RM, Hughes CM, Ventura AB, Ainslie E, Randall KT, Selseth AN, Rundstrom P, Herlache L, Lewis MS, Park H, Planer SL, Turner JM, Fischer M, Armstrong C, Zweig RC, Valvo J, Braun JM, Shankar S, Lu L, Sylwester AW, Legasse AW, Messerle 
M, Jarvis MA, Amon LM, Aderem A, Alter G, Laddy DJ, Stone M, Bonavia A, Evans TG, Axthelm MK, Fruh K, Edlefsen PT, Picker LJ (2018) Prevention of tuberculosis in rhesus macaques by a cytomegalovirus-based vaccine. Nat Med 24:130-143

73. Pages F, Galon J, Dieu-Nosjean MC, Tartour E, Sautes-Fridman C, Fridman WH (2010) Immune infiltration in human tumors: a prognostic factor that should not be ignored. Oncogene 29:1093-1102

74. Kalos M, June CH (2013) Adoptive T cell transfer for cancer immunotherapy in the era of synthetic biology. Immunity 39:49-60

75. Rosenberg SA, Restifo NP (2015) Adoptive cell transfer as personalized immunotherapy for human cancer. Science 348:62-68

76. June CH, O'Connor RS, Kawalekar OU, Ghassemi S, Milone MC (2018) CAR T cell immunotherapy for human cancer. Science 359:1361-1365

77. Vigneron N, Stroobant V, Van den Eynde BJ, van der Bruggen $P$ (2013) Database of T cell-defined human tumor antigens: the 2013 update. Cancer Immun 13:15

78. Klyushnenkova EN, Kouiavskaia DV, Parkins CJ, Caposio P, Botto S, Alexander RB, Jarvis MA (2012) A cytomegalovirusbased vaccine expressing a single tumor-specific CD8 + T-cell epitope delays tumor growth in a murine model of prostate cancer. J Immunother 35:390-399

79. Lee SH, Girard S, Macina D, Busa M, Zafer A, Belouchi A, Gros P, Vidal SM (2001) Susceptibility to mouse cytomegalovirus is associated with deletion of an activating natural killer cell receptor of the C-type lectin superfamily. Nat Genet 28:42-55

80. Lee SH, Zafer A, de Repentigny Y, Kothary R, Tremblay ML, Gros P, Duplay P, Webb JR, Vidal SM (2003) Transgenic expression of the activating natural killer receptor Ly49H confers resistance to cytomegalovirus in genetically susceptible mice. J Exp Med 197:515-526

81. Xu G, Smith T, Grey F, Hill AB (2013) Cytomegalovirus-based cancer vaccines expressing TRP2 induce rejection of melanoma in mice. Biochem Biophys Res Commun 437:287-291

82. Qiu Z, Huang H, Grenier JM, Perez OA, Smilowitz HM, Adler B, Khanna KM (2015) Cytomegalovirus-based vaccine expressing a modified tumor antigen induces potent tumor-specific CD8(+) $\mathrm{T}$-cell response and protects mice from melanoma. Cancer Immunol Res 3:536-546

83. Grenier JM, Yeung ST, Qiu Z, Jellison ER, Khanna KM (2017) Combining adoptive cell therapy with cytomegalovirus-based vaccine is protective against solid skin tumors. Front Immunol 8:1993

84. Erkes DA, Xu G, Daskalakis C, Zurbach KA, Wilski NA, Moghbeli T, Hill AB, Snyder CM (2016) Intratumoral infection with murine cytomegalovirus synergizes with PD-L1 blockade to clear melanoma lesions and induce long-term immunity. Mol Ther 24:1444-1455

85. Erkes DA, Wilski NA, Snyder CM (2017) Intratumoral infection by CMV may change the tumor environment by directly interacting with tumor-associated macrophages to promote cancer immunity. Hum Vaccin Immunother 13:1778-1785

86. Dekhtiarenko I, Ratts RB, Blatnik R, Lee LN, Fischer S, Borkner L, Oduro JD, Marandu TF, Hoppe S, Ruzsics Z, Sonnemann JK, Mansouri M, Meyer C, Lemmermann NA, Holtappels R, Arens R, Klenerman P, Fruh K, Reddehase MJ, Riemer AB, Cicin-Sain $\mathrm{L}$ (2016) Peptide processing is critical for T-cell memory inflation and may be optimized to improve immune protection by CMVbased vaccine vectors. PLoS Pathog 12:e1006072

87. Beyranvand Nejad E, Ratts RB, Panagioti E, Meyer C, Oduro JD, Cicin-Sain L, Fruh K, van der Burg SH, Arens R (2019) Demarcated thresholds of tumor-specific CD8 T cells elicited by MCMV-based vaccine vectors provide robust correlates of protection. J Immunother Cancer 7:25

88. Oduro JD, Redeker A, Lemmermann NA, Ebermann L, Marandu TF, Dekhtiarenko I, Holzki JK, Busch DH, Arens R, Cicin-Sain L (2016) Murine cytomegalovirus (CMV) infection via the intranasal route offers a robust model of immunity upon mucosal CMV infection. J Gen Virol 97:185-195

89. Redeker A, Welten SP, Arens R (2014) Viral inoculum dose impacts memory T-cell inflation. Eur J Immunol 44:1046-1057

90. Dekhtiarenko I, Jarvis MA, Ruzsics Z, Cicin-Sain L (2013) The context of gene expression defines the immunodominance hierarchy of cytomegalovirus antigens. J Immunol 190:3399-3409

91. Del Val M, Schlicht HJ, Ruppert T, Reddehase MJ, Koszinowski UH (1991) Efficient processing of an antigenic sequence for presentation by MHC class I molecules depends on its neighboring residues in the protein. Cell 66:1145-1153

92. Borkner L, Sitnik KM, Dekhtiarenko I, Pulm AK, Tao R, Drexler I, Cicin-Sain L (2017) Immune protection by a cytomegalovirus vaccine vector expressing a single low-avidity epitope. J Immunol 199:1737-1747

93. Aleksic M, Liddy N, Molloy PE, Pumphrey N, Vuidepot A, Chang KM, Jakobsen BK (2012) Different affinity windows for virus and cancer-specific T-cell receptors: implications for therapeutic strategies. Eur J Immunol 42:3174-3179

94. Ebert S, Lemmermann NA, Thomas D, Renzaho A, Reddehase MJ, Holtappels R (2012) Immune control in the absence of immunodominant epitopes: implications for immunotherapy of cytomegalovirus infection with antiviral CD8 T cells. Med Microbiol Immunol 201:541-550

95. Mueller SN, Mackay LK (2016) Tissue-resident memory T cells: local specialists in immune defence. Nat Rev Immunol 16:79-89

96. Morabito KM, Ruckwardt TR, Redwood AJ, Moin SM, Price DA, Graham BS (2017) Intranasal administration of RSV antigen-expressing MCMV elicits robust tissue-resident effector and effector memory $\mathrm{CD}^{+} \mathrm{T}$ cells in the lung. Mucosal Immunol 10:545-554

97. Smith CJ, Caldeira-Dantas S, Turula H, Snyder CM (2015) Murine CMV infection induces the continuous production of mucosal resident T cells. Cell Rep 13:1137-1148

98. Baumann NS, Torti N, Welten SPM, Barnstorf I, Borsa M, Pallmer K, Oduro JD, Cicin-Sain L, Ikuta K, Ludewig B, Oxenius A (2018) Tissue maintenance of CMV-specific inflationary memory T cells by IL-15. PLoS Pathog 14:e1006993

99. Ostermann E, Pawletko K, Indenbirken D, Schumacher U, Brune W (2015) Stepwise adaptation of murine cytomegalovirus to cells of a foreign host for identification of host range determinants. Med Microbiol Immunol 204:461-469

Publisher's Note Springer Nature remains neutral with regard to jurisdictional claims in published maps and institutional affiliations. 